\title{
In vitro molluscicidal activity of wormwood (Artemisia dubia) leaves against Oncomelania hupensis quadrasi
}

\author{
Charles Jardian C. Alinsub and Melvin A. Bagot
}

\begin{abstract}
There have been many efforts to eradicate the problem of schistosomiasis. One method is to control the growing snail population. This study aimed to determine the molluscicidal activity of wormwood (Artemisia dubia) leaves methanolic extract against adult and juvenile Oncomelania hupensis quadrasi. Using infusion technique, $80 \%$ methanol was used as solvent. There were eight treatments used: distilled water $\left(\mathrm{TO}_{(-) 1}\right)$ and $1 \%$ methanol $\left(\mathrm{TO}_{(-) 2}\right)$ as negative controls; $0.0002 \%\left(2 \mathrm{mg} \mathrm{L}^{-1}\right)$ niclosamide $\left(\mathrm{TO}_{+}\right)$as positive control; and $11.121 \%(\mathrm{~T} 1), 12.478 \%$ (T2), 14\% (T3), 15.708\% (T4) and 17.625\% (T5), which were replicated five times with 10 snails per replicate.

Results showed that for adults, the wormwood leaves methanolic extract was not statistically significant with the commercially available molluscicide, although $17.625 \%$ (T5) resulted in $82 \%$ mortality rate. For juveniles, the different extract concentrations resulted in 98 to $100 \%$ mortality, which were comparable to $0.0002 \%\left(2 \mathrm{mg} \mathrm{L}^{-1}\right)$ niclosamide and were considered highly effective based on Reik \& Keitz (1954) and European Agency for the Evaluation of Medicinal Products (EMEA). Thus, wormwood leaves methanolic extract has a promising molluscicidal activity against adult snails at a concentration of $17.625 \%$, and at all concentrations for the juvenile snails of 0 . hupensis quadrasi. The $\mathrm{LC}_{50}$ of the adult and juvenile snails were $14.075 \%$ and $10.294 \%$, respectively.

Secondary metabolites that were found positive during the qualitative phytochemical analysis with the extract were tannins, saponins, and terpenoids. The mortality of the snails can be attributed to the bioactivity of the secondary metabolites present that may be acting in combination or individually.
\end{abstract}

Keywords: Artemisia dubia, wormwood, Oncomelania hupensis quadrasi, molluscicide

*College of Veterinary Medicine, Visayas State University, Visca, Baybay City, Leyte, Philippines 6521

\footnotetext{
*Corresponding Author. Address: College of Veterinary Medicine, Visayas State University, Visca, Baybay City, Leyte, Philippines 6521; Email:bagot.melvin@vsu.edu.ph

DOI:10.32945/atr4112.2019
} 
In vitro molluscicidal activity of wormwood

\section{INTRODUCTION}

Synthetic molluscicides have major drawbacks on their efficacy (Michael et al 2013). This prompted the growing interest on investigating the potential of plants as alternatives. In schistosomiasis endemic areas, especially in poor countries, snail control is a challenge due to the very high cost of synthetic compounds. One of the methods in controlling schistosomiasis is to control the snail population with the use of molluscicides. Synthetic molluscicides cause stress on the water balance systems (McCullough et al 1980) and snails have evolved resistance (Duke et al 2010). This leads to increase of interest on plant molluscicides due to low cost (Adewunmi 1991).

Over the years, many researches have been conducted to look for a solution to control the snail population in the hopes of eradicating schistosomiasis through the use of plants (Hostettmann 1982, Ojewole \& John 2004). In this study, wormwood (Artemisia dubia) plant was tested against Oncomelania hupensis quadrasi. Wormwood is an effective herbal medicine in treating a variety of disorders of the digestive tract. It is found to have antifungal, antibacterial, expectorative and antiasthmatic properties (Hoffman 2003). In addition, the plant is thought to be effective against a wide range of parasitic infections(Harris \& Harris 2003).

\section{MATERIAL AND METHODS}

\section{Preparation of Wormwood Leaves}

Wormwood leaves regardless of maturity were collected within Baybay City, Leyte, Philippines and was further identified for correct classification; these were washed with tap water and air-dried at room temperature for $48 \mathrm{~h}$. After drying, the leaves were chopped and air-dried further for 7 days.

\section{Plant Leaves Extraction}

Plant extraction through methanol infusion for $48 \mathrm{~h}$ was performed as previously described by Macabeo et al (2005). Methanol (80\%) was used as it is an ideal solvent for plant active compounds extraction. However, it is more toxic than ethanol but is easily evaporated from the extract at low temperature (Zhao et al 2009). According to Azmir et al (2013), methanol is toxic if it is still present in the extract but is useful when extracting certain phytochemicals and unique compounds. After infusion, the collected filtrate was concentrated with a rotary evaporator $\left(30^{\circ} \mathrm{C}\right)$.

\section{Collection of Oncomelania hupensis quadrasi}

Staff from the Medical Zoology Laboratory- Schistosomiasis Research and Training Center of Palo, Leyte, Philippines assisted the collection of 0 . hupensis quadrasi snails at Brgy. Guindag-an, Lumbia Swamp, Tanauan Leyte. Adult and juvenile snails were placed and stored in a glass jar layered with moistened filter paper; these were transferred to the Diagnostic Laboratory of the College of Veterinary Medicine of Visayas State University, Philippines. 


\section{Assay of Molluscicidal Activity}

There were eight treatment groups. Each treatment group had a corresponding five replicates, with 10 adult or juvenile snails per replicate. Each replicate was flooded uniformly with varying concentrations of wormwood methanolic extract (WLME). The different treatment groups were: $\mathrm{TO}_{(-) 1}$ (distilled water), $\mathrm{TO}_{(-) 2}(1 \%$ methanol) as negative controls; $\mathrm{TO}_{(+)}\left(0.0002 \%\left(2 \mathrm{mg} \mathrm{L}^{-1}\right)\right.$ of niclosamide) as positive control; $11.121 \%$ WLME (T1), $12.478 \%$ WLME (T2), 14\% WLME(T3), $15.708 \%$ WLME (T4) and $17.625 \%$ WLME (T5). The different concentrations were based from the results of the lethal concentration that could kill $50 \%\left(\mathrm{LC}_{50}\right)$. The $\mathrm{LC}_{50}$ was established first using different concentrations of WLME $(14 \%, 16 \%, 18 \%$ \& $20 \%)$. Meanwhile, $50 \%$ mortality was observed at $14 \%$ while other concentrations resulted to more than $50 \%$ mortality. Then, using the logarithmic methods of Guevara \& Recio (2005), the concentrations used in the final study were established.

Flooding technique was used in the assay, using only the live and viable snails. Juvenile and adult snails were sorted out in different petri plates for separate treatments. Juvenile snails measure $2.0-3.0 \mathrm{~mm}$ long while adult snails measure $3.1-3.5 \mathrm{~mm}$ long. They were exposed with the WLME for $24 \mathrm{~h}$. The plates were covered with cloth and tied with rubber bands. On the following day, the snails were transferred to another petri plate with distilled water and left for another $24 \mathrm{~h}$ to further observe whether it is dead or alive (Rug \& Ruppel 2001). Live snails were active after treatment, or when their head, belly-foot part and tentacles were extended as if attempting to crawl. To differentiate snails that were alive or dead, motility and sensitivity tests were conducted. For the motility test, the snails were transferred to another petri plate with distilled water layered with filter paper marked with $5 \mathrm{~mm}$ diameter circles; those that moved out of the circles were considered alive while those that remained immobile and retained their positions after $3 \mathrm{~h}$ were tested for sensitivity testing. For sensitivity testing, the snails were viewed with the use of a microscope (10X) and were prodded with a needle. When prodded, live snails usually retract their operculum; snails that were immobile but sensitive to prodding were considered alive.

Different formulas were used to determine the efficacy of WLME: 1) percent mortality and \% efficacy based on Reik and Keitz (1954); wherein $<70 \%$ mortality is ineffective, $71-80 \%$ mortality is effective and $81-100 \%$ mortality is said to be highly effective and 2) European Agency for the Evaluation of Medicinal Products (EMEA 2000 ); wherein $<90 \%$ mortality is not effective.

\section{Phytochemical Analysis of the Plant Leaves}

Following the procedures as previously described by Senguttuvan, Paulsamy, Karthika (2014), qualitative phytochemical analysis of the WLME was conducted by testing the following secondary metabolites through different procedures and tests: alkaloids (Mayer's test, Wagner's test); tannins (Tannins test); saponins (Froth test); flavonoids (Alkaline Reagent test, Lead acetate test, Ferric Chloride test); and terpenoids (Chloroform \& Sulfuric acid test). A grading system of the phytochemicals was described in the following manner: $(+)$ positive, $(-)$ traces and (0) undetected. 
In vitro molluscicidal activity of wormwood

\section{Statistical Analysis and Experimental Design}

The experiment was laid out in Completely Randomized Design (CRD). ANOVA was used to analyze the variation among groups and Tukey's HSD (honestly significant difference) test to determine comparison among groups.

\section{RESULTS AND DISCUSSION}

Variation in the number of dead adult snails was observed and dose-dependent (Table 1). The efficacy of the WLME according to percent mortality rate and its equivalent \% efficacy based on Reik \& Keitz (1954) were: for $17.625 \%$ WLME (T5), highest mortality rate of $82 \%$ which is highly effective; followed by $15.708 \%$ WLME (T4), with $74 \%$ mortality which is considered effective; and all the three remaining treatments $14 \%$ (T3), $12.478 \%$ (T2), 11.121\% (T1) were considered not effective with mortality rates of $60 \%, 26 \%$ and $6 \%$, respectively. However, based on to the EMEA, all treatments were considered not effective since their mortality rates were below $90 \%$. Moreover, $17.625 \%$ WLME (T5) which had the highest mortality rate was not statistically comparable with $0.0002 \%\left(2 \mathrm{mg} \mathrm{L}^{-1}\right)$ niclosamide, with $100 \%$ mortality rate. The $\mathrm{LC}_{50}$ of WLME for adults was $14.075 \%$ based on Probit analysis at $95 \%$ confidence level.

Table 1. Mean \% mortality of wormwood leaves crude methanolic extract against adult and juvenile Oncomelania hupensis quadrasi snails

\begin{tabular}{ccccccc}
\hline \multirow{2}{*}{ Treatment } & \multicolumn{3}{c}{ Adult Snails } & \multicolumn{3}{c}{ Juvenile Snails } \\
\cline { 2 - 7 } & Average & $\begin{array}{c}\text { Dead } \\
\text { (Ave) }\end{array}$ & $\begin{array}{c}\text { Mortality } \\
\text { Rate }(\%)\end{array}$ & Average & $\begin{array}{c}\text { Dead } \\
\text { (Ave) }\end{array}$ & $\begin{array}{c}\text { Mortality } \\
\text { Rate }(\%)\end{array}$ \\
\hline $\mathrm{TO}_{(-) 1}$ & 10 & 0 & $0^{\mathrm{a}}$ & 10 & 0 & $0^{\mathrm{a}}$ \\
$\mathrm{TO}_{(-) 2}$ & 10 & 0 & $0^{\mathrm{a}}$ & 10 & 0 & $0^{\mathrm{a}}$ \\
$\mathrm{T0}(+)$ & 10 & 10 & $100^{\mathrm{e}}$ & 10 & 10 & $100^{\mathrm{b}}$ \\
$\mathrm{T} 1$ & 10 & 0.6 & $6^{\mathrm{a}}$ & 10 & 9.8 & $98^{\mathrm{b}}$ \\
$\mathrm{T} 2$ & 10 & 2.6 & $26^{\mathrm{b}}$ & 10 & 10 & $100^{\mathrm{b}}$ \\
$\mathrm{T} 3$ & 10 & 6 & $60^{\mathrm{c}}$ & 10 & 10 & $100^{\mathrm{b}}$ \\
$\mathrm{T} 4$ & 10 & 7.4 & $74^{\mathrm{d}}$ & 10 & 10 & $100^{\mathrm{b}}$ \\
$\mathrm{T} 5$ & 10 & 8.2 & $82^{\mathrm{d}}$ & 10 & 10 & $100^{\mathrm{b}}$ \\
\hline
\end{tabular}

Means with different superscript letters are significantly different at $p<0.05$

No. of replicates per treatment $=5$

No. of snails per replicate $=10$

For the juvenile snails, there was no variation in the level of mortality (Table 1). The efficacy of the WLME according to mortality rate and its equivalent \% efficacy based on Reik and Keitz (1954) were: 11.121\% WLME (T1) had the lowest mean mortality rate of $98 \% ; 12.478 \%$ WLME (T2), 14\% (T3), $15.708 \%$ (T4), and $17.625 \%$ WLME (T5) all had $100 \%$ mortality and were considered highly effective. Based on EMEA, all the treatments were also considered effective. All five treatments were also statistically comparable with the commercially available molluscicide. The LC $_{50}$ of the WLME for juveniles was $10.294 \%$ based on Probit analysis at $95 \%$ confidencelevel. 
Phytochemical analysis was conducted in order to determine the possible secondary metabolites as bioactive components that might have contributed to the molluscicidal activity of the WLME. Based on the phytochemical tests conducted, tannins, terpenoids, and saponins were present. The positive and negative reactions were shown as qualitative interpretation of the results (Table 2). A blueblack and brownish green discoloration of the test solution indicated condensed tannins; terpenoids as reddish brown discoloration of the test solution; saponins, was indicated as copious lather formation. All tests for alkaloids and flavonoids were negative.

Table 2. Phytochemical analysis of plant secondary metabolites from wormwood leaves crude methanolic extract

\begin{tabular}{ll}
\hline Secondary metabolites & Qualitative grading \\
\hline Alkaloids & 0 \\
Tannins & ++ \\
Terpenoids & +++ \\
Flavonoids & 0 \\
Saponins & ++ \\
\hline+++ strongly positive, ++ moderately positive, + weakly positive, - traces, 0 undetected Interpretation was based on the study of \\
Senguttuvan et al (2014)
\end{tabular}

The WLME exhibited potential molluscicidal activity against adult and juvenile 0 . hupensis quadrasi snails at $24 \mathrm{~h}$ exposure. The efficacy based on the mortality rates attained could be attributed to the secondary metabolites identified during the phytochemical test such as tannins, terpenoids, and saponins. These classes of compounds, independently or in combination, may be responsible for the mortality of snails. This finding conforms to the report of Aladesanmi (2007) in which similar constituents were found to exhibit molluscicidal activity.

Schultz (2018) and Smith, Zoetendal, and Mackie (2005) indicated that tannins bind to proteins and enzymes that may block digestion of an organisms. On the other hand, Aladesanmi (2007) and Hostettmann (1982) indicated that saponins exhibit strong molluscicidal properties. Moreover, Bak (2013) illustrated that saponins can disrupt cell membranes, cause cell death, and may ultimately kill herbivores and pests. For terpenoids, their molluscicidal activity could possibly be due to the action of thiol-containing enzymes. The action of terpenes or terpenoids most likely involves the alkylation(s) of the essential enzymes of the organism's metabolism(Knobloch et al 1989, McGarvey \& Croteau 1995).

Although the level of bioactive compounds present in the plant depends on the season, other factors like the type of soil, temperature, altitude, radiation, atmosphere, light exposure, and nutrition can also influence the variability in plant metabolite levels that could affect the safety and the reliability of the plant's efficacy(Pavarini et al 2012).

On the variability between adult and juvenile mortality, Mohammed (2013) and Arufe (2004), explained that early life stages of snails are more sensitive compared to adults. Often, these were due to differences between life stages in the morphological, physiological, and even biochemical characteristics. Such factors include, but are not limited to 1 ) juvenile's organ systems may be sensitive to the 
In vitro molluscicidal activity of wormwood

effects of toxicants, and 2) differential rates of absorption or uptake distribution or detoxification (Aladesanmi 2007, Mohammed 2013). Also, toxicants may induce the synthesis of some specific proteins like oxygenase and methyllotheinions which may play a role in detoxifying and sequestering toxicants, thus rendering or reducing their toxic effect. Additionally, early life stages could be lacking fullyexpressed enzyme systems needed for efficient detoxification and elimination of toxicants which could be due to the slow development of their organs (Anto et al 2005, Lardans \& Dissous 1998).

\section{CONCLUSION}

Wormwood leaves methanolic crude extract has a potential molluscicidal activity, thus, can be used as an alternative molluscicides against 0 . hupensis quadrasi. Although the results of the efficacy against adult is not comparable to the commercially available molluscicide, the concentration rate can be increased to improve efficacy. Field trial of the extract is highly recommended.

\section{COMPETING INTERESTS}

The authors declare no competing interests.

\section{ACKNOWLEDGMENTS}

Special thanks to the College of Veterinary Medicine of the Visayas State University, Philippines headed by Dr. Eugene Lañada and to Dr. Carl Leonard Pradera as member of the research committee.

\section{REFERENCES}

Adewunmi CO. 1991. Plant molluscicides: potential of aridan, Tetrapleura tetraptera, for schistosomiasis control in Nigeria. Science of the Total Environment 102:21-33

Aladesanmi AJ. 2007. Tetrapleura tetraptera: Molluscicidal activity and chemical constituents. African Journal of Traditional, Complementary and Alternative Medicines 4(1):23-36

Anto F, Aryeetey ME, Anyorigiya T, Asoala V \& Kpikpi J. 2005. The relative susceptibilities of juvenile and adult Bulinus globosus and Bulinus truncatus to the molluscicidal activities in the fruit of Ghanaian Blighia sapida, Blighia unijugata and Balanites aegyptiaca. Annals of Tropical Medicine \& Parasitology 99(2):211-217. https://doi.org/10.1179/136485905X24229

Arufe MI, Arellano J, Moreno MJ \& Sarasquete C. 2004. Toxicity of a commercial herbicide containing terbutryn and triasulfuron to seabream (Sparus aurata L.) larvae: a comparison with the Microtox test. Ecotoxicology and Environmental Safety 59(2):209-216. https://doi.org/10.1016/j.ecoenv.2003.12.010

Azmir J, Zaidul ISM, Rahman MM, Sharif KM, Mohamed A, Sahena F, ... Omar AKM 2013. Techniques for extraction of bioactive compounds from plant materials: A review. Journal of Food Engineering 117(4):426-436. https://doi.org/10. 1016/j.jfoodeng.2013.01.014 
Bak S. 2013. Saponin structure-activity relationships: biological activity, ecological function and evolution - University of Copenhagen. Retrieved June 6,2018, from https://plen.ku.dk/english/research/plant_biochemistry/ terpenoids/saponin-activity-ecology/

Duke SO, Cantrell CL, Meepagala KM, Wedge DE, Tabanca N \& Schrader KK. 2010. Natural Toxins for Use in Pest Management. Toxins 2(8):1943-1962. https://doi.org/10.3390/toxins2081943

EMEA. 2000. European Agency for the Evaluation of Medicinal Products (Vol. 26) Guevara B and Recio B. 2005. A Guidebook to plant screening: phytochemical and biological. Manila: Research Center for the Natural Sciences, University of Santo Tomas

Harris B and Harris R. 2003. A clinical guide to blending liquid herbs. herbal formulas for the individual patient. Retrieved May 25, 2018, from https://ww w.infona.pl/resource/bwmeta1.element.elsevier-8211ec9b-44da-3ace-a55c88d98d3effbc

Hoffman D. 2003. Medical Herbalism: The Science and Practice of Herbal Medicine - David Hoffmann - Google Books. Retrieved May 25, 2018, from https://books.google.com.ph/books?hl=en\&lr=\&id=e10oDwAAQBAJ\&oi=fnd \&pg=PT6\&dq=Medicinal+Herbalism:+The+Science+and+Practice+of+Herbal +Medicine\&ots=iJQc_7G9eY\&sig=4tEmqa2maBarmpRCyXe04_yjCY0\&redir_ esc $=\mathrm{y} \# \mathrm{v}=$ onepage $\& \mathrm{q}=$ Medicinal\%20Herbalism\%3A\%20The $\% 20$ Science $\% 20 \mathrm{a}$ nd\%20Practice $\% 20$ of $20 \mathrm{Herbal} \% 20$ Medicine $\& \mathrm{f}=$ false

Hostettmann K. 1982. Saponins with Molluscicidal Activity from Hedera helixL. Helvetica Chimica Acta 63(3):606-609. https://doi.org/10.1002/hlca.19800 630307

Knobloch K, Pauli A, Iberl B, Weigand H \& Weis N. 1989. Antibacterial and Antifungal Properties of Essential Oil Components. Journal of Essential Oil Research 1(3):119-128. https://doi.org/10.1080/10412905.1989.9697767

Lardans V and Dissous C. 1998. Snail Control Strategies for Reduction of Schistosomiasis Transmission. Parasitology Today 14(10):413-417. https://doi.org/10.1016/S0169-4758(98)01320-9

Macabeo APG, Krohn K, Gehle D, Read RW, Brophy JJ, Cordell GA, ... Aguinaldo AM. 2005. Indole alkaloids from the leaves of Philippine Alstonia scholaris. Phytochemistry 66(10):1158-1162.https://doi.org/10.1016/j.phytochem.20 05.02.018

McCullough FS, Gayral P, Duncan J \& Christie JD. 1980. Molluscicides in schistosomiasis control. Bulletin of the World Health Organization 58(5):681-689

McGarvey DJ and Croteau R. 1995. Terpenoid metabolism. The Plant Cell 7(7):1015-1026

Michael ES, Yole D, Musila MF, Kutima H \& Kareru P. 2013. Assessment of Molluscicidal, Cercericidal and Miracicidal Activities of Crude Extracts of Azadirachta indica and Entada leptostachya. Journal of Biology, Agriculture and Healthcare 3(5):11-17

Mohammed A. 2013. January 23. Why are Early Life Stages of Aquatic Organisms more Sensitive to Toxicants than Adults?. Retrieved June 6, 2018, from https://www.intechopen.com/books/new-insights-into-toxicity-and-drugtesting/why-are-early-life-stages-of-aquatic-organisms-more-sensitive-totoxicants-than-adults- 
In vitro molluscicidal activity of wormwood

Ojewole 0 and John A. 2004. Indigenous plants and schistosomiasis control in south africa:molluscicidal activity of some zulu medicinal plants. Boletín Latinoamericano y del Caribe de Plantas Medicinales y Aromáticas 3(1):8-22. Retrieved from http://www.redalyc.org/resumen.oa?id=85630104

Pavarini DP, Pavarini SP, Niehues M \& Lopes NP. 2012. Exogenous influences on plant secondary metabolite levels. Animal Feed Science and Technology 176(1-4): 5-16

Reik TJ and Keitz B. 1954. Studies on anthelmintics in cattle. Australian Research Journal 33:162-173

Rug M and Ruppel A. 2001. Toxic activities of the plant Jatropha curcas against intermediate snail hosts and larvae of schistosomes. Tropical Medicine \& International Health 5(6):423-430. https://doi.org/10.1046/j.13653156.2000.00573.x

Schultz J. 2018. Secondary Metabolites in Plants - Biology Encyclopedia - body, function, animal, organisms, DNA, hormone, used, specific, structure, role, major. Retrieved June 6, 2018, from http://www.biologyreference.com/ReSe/Secondary-Metabolites-in-Plants.html

Senguttuvan J, Paulsamy S \& Karthika K. 2014. Phytochemical analysis and evaluation of leaf and root parts of the medicinal herb, Hypochaeris radicata L. for in vitro antioxidant activities. Asian Pacific Journal of Tropical Biomedicine 4:S359-S367. https://doi.org/10.12980/APJTB.4.2014C1030

Smith AH, Zoetendal E \& Mackie RI. 2005. Bacterial Mechanisms to Overcome Inhibitory Effects of Dietary Tannins. Microbial Ecology 50(2):197-205. https://doi.org/10.1007/s00248-004-0180-x

Zhao X, Cheng K \& Liu D. 2009. Organosolv pretreatment of lignocellulosic biomass for enzymatic hydrolysis. Applied Microbiology and Biotechnology 82(5):815. https://doi.org/10.1007/s00253-009-1883-1 